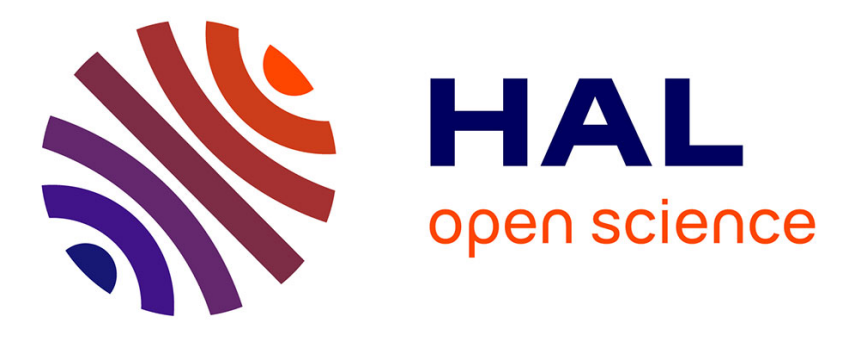

\title{
Chalcogen bonding interactions in chelating, chiral bis(selenocyanates)
}

Huu-Tri Huynh, Olivier Jeannin, Emmanuel Aubert, Enrique Espinosa, Marc

Fourmigue

\section{- To cite this version:}

Huu-Tri Huynh, Olivier Jeannin, Emmanuel Aubert, Enrique Espinosa, Marc Fourmigue. Chalcogen bonding interactions in chelating, chiral bis(selenocyanates). New Journal of Chemistry, 2021, 45 (1), pp.76-84. 10.1039/d0nj05293k . hal-03127392

\section{HAL Id: hal-03127392 \\ https://hal.science/hal-03127392}

Submitted on 22 Feb 2021

HAL is a multi-disciplinary open access archive for the deposit and dissemination of scientific research documents, whether they are published or not. The documents may come from teaching and research institutions in France or abroad, or from public or private research centers.
L'archive ouverte pluridisciplinaire HAL, est destinée au dépôt et à la diffusion de documents scientifiques de niveau recherche, publiés ou non, émanant des établissements d'enseignement et de recherche français ou étrangers, des laboratoires publics ou privés. 


\section{Chalcogen bonding interactions in chelating, chiral bis(selenocyanates) $\dagger$}

Huu-Tri Huynh, ${ }^{a}$ Olivier Jeannin, ${ }^{a}$ Emmanuel Aubert, ${ }^{b}$ Enrique Espinosa ${ }^{b}$ and Marc Fourmigué ${ }^{\star a}$

${ }^{a}$ Univ Rennes, CNRS, ISCR (Institut des Sciences Chimiques de Rennes) - UMR 6226, F-35000 Rennes, France.E-mail: marc.fourmigue@univ-rennes1.fr

${ }^{b}$ Université de Lorraine, CNRS, CRM2 , F-54000 Nancy, France

$\dagger$ Electronic supplementary information (ESI) available: Computational details. CCDC 2040289-2040296. For ESI and crystallographic data in cif or other electronic format see DOI: 10.1039/XXXXXX

\section{Abstract}

Introduction of methyl substituents on the achiral 1,2-bis(selenocyanatomethyl)benzene leads to a novel chelating ChB donor, namely 1,2-bis(1-selenocyanatoethyl)benzene (1), as a mixture of three diastereomers, the two anti enantiomers and the syn (meso) form. Structure determinations show the recurrent formation of short Se $\bullet \bullet N \equiv C$ ChB interactions in both the anti (racemic mixture) and syn isomers. Co-crystallization of anti-1 with 4,4'-bipyridine affords a 2:1 adduct, (anti-1) $)_{2}$ (bipy), with one very short $\mathrm{Se} \bullet \bullet \mathrm{N}_{\mathrm{Py}} \mathrm{ChB}(\mathrm{RR}=0.87)$. Co-crystallization of anti-1 with tetraphenylphosphonium halides $\left(\mathrm{Cl}^{-}, \mathrm{Br}^{-}, \mathrm{I}^{-}\right)$provides 1:1 adducts while a 2:1 adduct is isolated between syn-1 and $\mathrm{Et}_{4} \mathrm{NCl}$, formulated as $\mathrm{Et}_{4} \mathrm{~N}^{+}\left[(\operatorname{syn}-\mathbf{1})_{2} \mathrm{Cl}^{-}\right]$. Comparison of chloride chelation with anti-1 and syn-1 shows much shorter (NC)Se $\bullet \cdot \mathrm{Cl}^{-} \mathrm{ChB}$ interactions with the syn isomer, tentatively rationalized on the basis of theoretical calculations of (i) the electrostatic surface potential of neutral ChB donors and (ii) the chloride BSSE complexation energy. 


\section{Introduction}

Non-covalent interactions ${ }^{1}$ are currently developing as a cross-field area encompassing many different topics found in crystal engineering, anion recognition and transport, catalysis, biochemistry, material science. Following the huge development of halogen bonding (XB) in the last 25 years, ${ }^{2}$ it became clear that elements of group 14, 15 and 16 of the periodic table were also prone to exhibit electrophilic sites prone to interact with charge-concentrated area, in a way very similar to that shown by halogens where the development of an electron-deficient region (also called sigma-hole) ${ }^{3}$ in the prolongation of the covalent bond to the halogen allows for strong and directional interactions with Lewis bases. These newcomers to the field, described as tetrel $(\mathrm{TrB}),{ }^{4}$ pnictogen $(\mathrm{PnB})^{5}$ and chalcogen bonds $(\mathrm{ChB}),{ }^{6}$ albeit much less developed than $\mathrm{XB}$, present some specificities and offer new possibilities particularly on the field of supramolecular self-assembly and crystal engineering, ${ }^{6 a, 7}$ catalysis, ${ }^{8}$ anion recognition ${ }^{9}$ and transport, ${ }^{10}$ biochemistry. ${ }^{11}$ If we focus on $\mathrm{ChB}$, one main difference with $\mathrm{XB}$ is the presence, on the chalcogen atom when properly activated, of not one but two electron-depleted regions, located approximately in the extension of the two covalent bonds to the chalcogen. ${ }^{3,12,13}$ This added element of complexity has several important structural implications such as: (i) possible deviations between the $\mathrm{C}_{\mathrm{i}}-\mathrm{Ch}$ and $\mathrm{Ch} \bullet \bullet \mathrm{X}(\mathrm{X}=$ Lewis base) axes, and (ii) possibility for dissymmetry of chalcogen substitution implying a dissymmetry of the two $\sigma$-hole area. As a consequence, the very strong predictability of $\mathrm{XB}$ interactions finds in the analogous $\mathrm{ChB}$ systems some limitations, which have hampered its extensive use in crystal engineering strategies. Several prominent examples have however successfully overcome these problems, such as the self-assembly of 1,2-tellurazole 2-oxides into a variety of supramolecular aggregates,${ }^{14}$ the use of bis-(selenophene/tellurophene) derivatives as chelating systems toward anions (Scheme 1a), ${ }^{10,15,16}$ or double chalcogen bonding interactions exhibited by benzo-1,3chalcogenazoles ${ }^{17}$ or chalcogenadiazoles. ${ }^{18}$ 
(a)
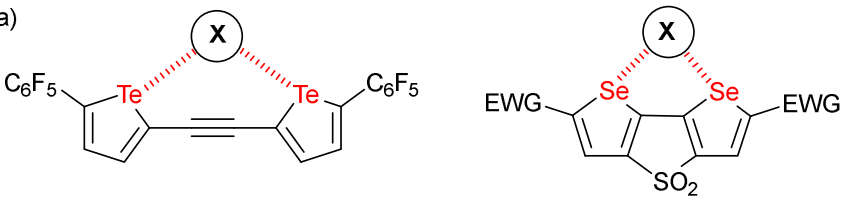

(b)
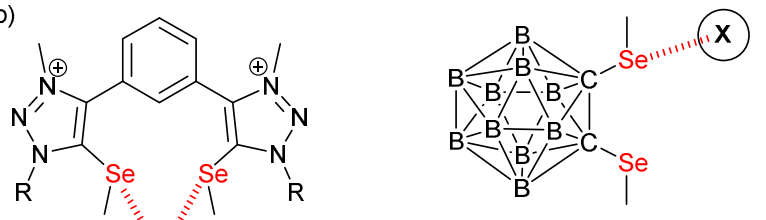

(x)

(c)

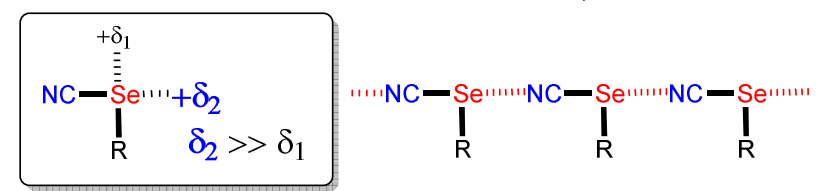

Scheme 1 (a) Structures of reported ChB donors chelating halides. (b) Systems with strongly asymmetric selenium activation (c) Organic selenocyanates: sigma-holes and solid-state association.

Along these lines, one attempt to restore in $\mathrm{ChB}$ systems the strong directionality offered by halogens consists in functionalizing the chalcogen atom with only one strong electronwithdrawing substituent, as for example in rotaxanes incorporating selenomethyltriazolium moieties, ${ }^{19}$ in selenomethyl- or telluromethyl-acetylenes, ${ }^{20}$ in icosahedral ortho-carboranes substituted with two methylseleno or methyltelluro groups (Scheme $1 b$ ), ${ }^{21}$ or in selenocyanate derivatives R-SeCN (Scheme 1c). ${ }^{22,23}$ In such compounds, the electron-withdrawing character of the nitrile substituents strongly activates one of the two $\sigma$-holes, in the prolongation of the $\mathrm{NC}-\mathrm{Se}$ bond, allowing to recover the predictability of interaction with Lewis bases. Indeed, selenocyanates themselves most often crystalize into chains $\bullet \bullet N C-(\mathrm{R}) \mathrm{Se} \bullet \bullet N C-(\mathrm{R}) \mathrm{Se} \bullet \bullet$ where the lone pair of the nitrogen atom of the nitrile interacts through $\mathrm{ChB}$ with the selenium atom with Se•••N distances around 3.0 $\AA$, that is a reduction ratio RR (defined as the actual interatomic distance over the sum of the van der Waals radii) around 0.86. Recently, we reported several bis- or tetrakis-substituted selenocyanate derivatives such as A-D in Scheme $2 \mathrm{a},{ }^{23}$ easily prepared from the corresponding benzylic bromides and $\mathrm{KSeCN}$, which were shown to organize in the solid state with these recurrent chain-like motifs. These $\mathrm{ChB}$ interactions are notably enhanced when the selenocyanate is faced with stronger Lewis bases such as pyridines ${ }^{24}$ or halide anions. ${ }^{25}$ A remarkable feature of the ortho derivative A (or the 1,2,4,5-tetrakis derivative D) is its ability to chelate one single atom through the two selenium atoms, giving rise to seven-membered rings with either neutral (DMF) or anionic (halides) Lewis bases 
(Scheme 2b). These interactions were also confirmed in solution by ${ }^{13} \mathrm{C}$ and ${ }^{77} \mathrm{Se} \mathrm{NMR} .{ }^{26}$ With the $\mathrm{ChB}$ donors $\mathrm{A}$ and $\mathrm{D}$, two specific conformations of the ortho-selenocyanatomethyl arms were observed on the solid state upon halide chelation, namely syn or anti, depending on the halide anion, its coordination number and the associated counter ion, without possibility to evaluate the relative stability of both conformations. In order to clarify this point and possibly favor one over the other conformation in these halide recognition processes, we designed an ortho bis(selenocyanate) derivative $\mathbf{1}$ analogous to A, but bearing an extra methyl group on each benzylic bridge (Scheme 2c). Compound 1 does thus exist as three diastereomers, the two anti enantiomers and the syn (meso) form. We describe here its synthesis, separation of the anti and syn forms and their association with neutral (4,4'-bipyridine) and charged (halide anion) Lewis bases. This novel $\mathrm{ChB}$ donor provides also a rare example of introduction of chirality in chalcogen-bonded systems. ${ }^{27}$ Indeed, only a few examples of selenylation reagents were

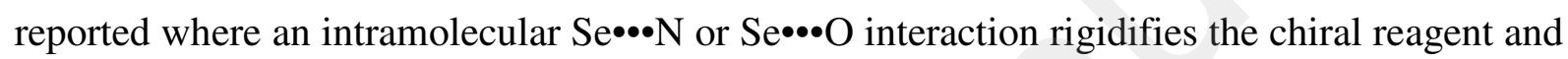
thus allows for stereochemical control, ${ }^{6 c, 28}$ while recently a planar chiral ferrocenyl plateform was functionalized with iodomethyl- and selenomethyl-ethynyl moieties ${ }^{29}$ for evaluation in the Ritter reaction. ${ }^{30}$
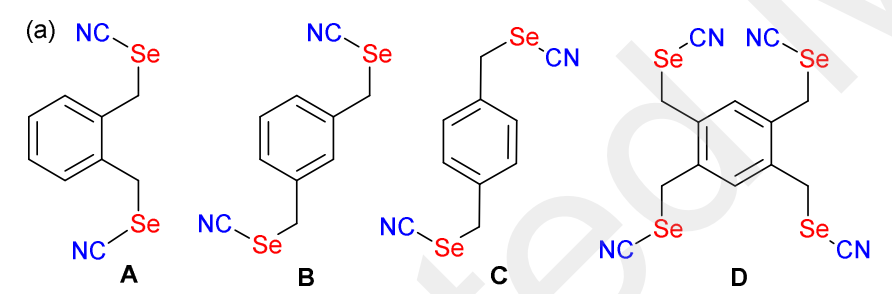

(b)

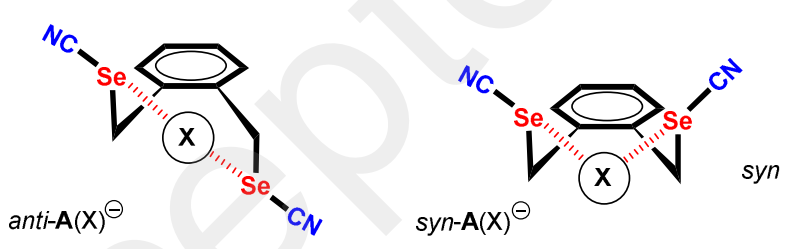

(c)

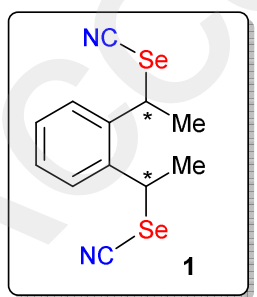

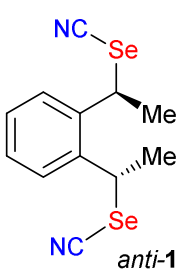

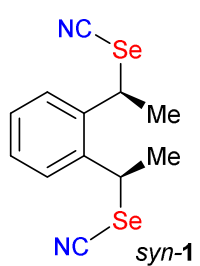

Scheme 2 Benzylic selenocyanates and their halide chelates. 


\section{Results and discussion}

Syntheses. The preparation of $\mathbf{1}$ is based on the nucleophilic substitution of 1,2-bis(1bromoethyl)benzene 2 with $\mathrm{KSeCN}$ (Scheme 3). The preparation of 2 from reaction of 1,2diethylbenzene with NBS has been reported to afford a diastereoisomeric mixture in a 3:1 ratio. ${ }^{31}$ Recrystallization was reported to yield a crystalline material composed essentially of the majority compound, whose stereochemistry was not assigned at that time. Based on the product obtained from the majority dibromo compound when reacted with glycine, ${ }^{32}$ the main diastereoisomer was later shown to be the anti one.

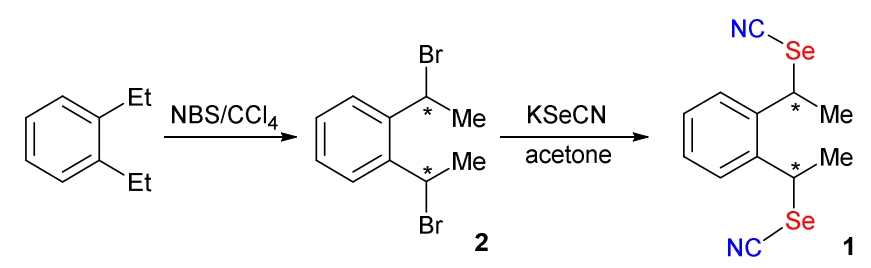

Scheme 3. Synthetic path to 1.

We have performed the bromination reaction of 1,2-diethylbenzene in the same conditions and isolated indeed a 70:30 anti-syn mixture. Recrystallization from hexane afforded the pure anti isomer whose stereochemistry was confirmed here by single crystal X-ray diffraction. Concentration of the mother liquors gives a 23:77 anti-syn mixture based on NMR. The dibromo derivative anti-2 crystallizes in the monoclinic system, S. G. $P 2_{1} / n$ with one molecule in general position (Figure 1a). No short intermolecular $\mathrm{Br} \bullet \bullet \mathrm{Br}$ are identified. Nucleophilic substitution with $\mathrm{KSeCN}$ was not stereochemically conservative and afforded a mixture of antiand syn-1, in 3:1 ratio when performed from pure anti-2. Recrystallization from acetone allowed to isolate anti-1 in a pure form. It crystallizes in the monoclinic system, S. G. $P 2{ }_{1} / a$ with one molecule in general position (Figure $1 \mathrm{~b}$ ) together with one of the $\mathrm{SeCN}$ moieties disordered on two positions with 60:40 refined occupancy. From the concentrated mother liquors, some crystals of syn-1 were isolated with difficulties after hexane diffusion. The syn isomer was found to crystallize in the monoclinic system, S. G. $P 2{ }_{1} / c$ with one molecule in general position (Figure 1c). 

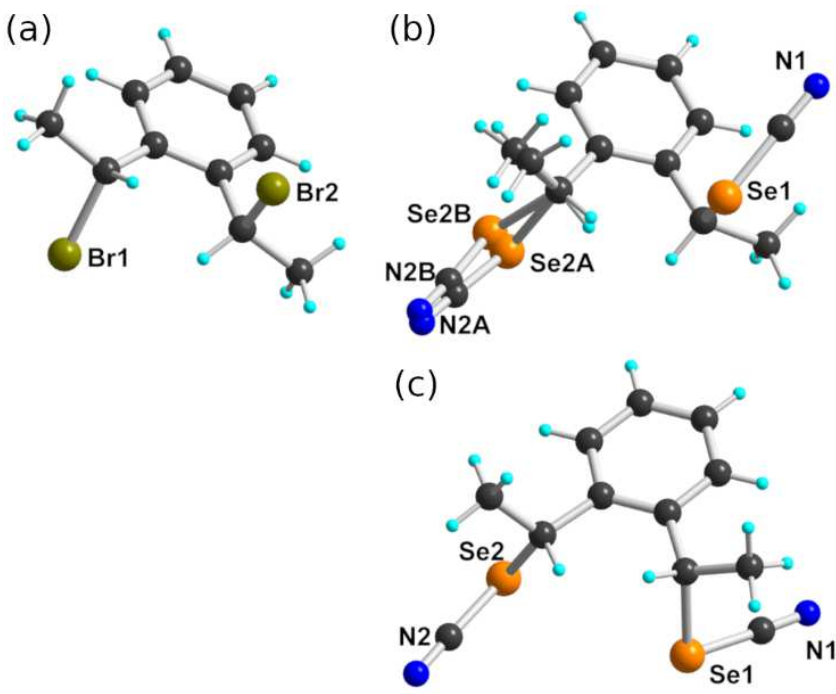

Fig. 1 Detail of the molecular structures of (a) anti-2, (b) anti-1, (c) syn-1.

The solid-state organization of anti-1 exhibits characteristic $\mathrm{ChB}$ interactions found in organic selenocyanates. As shown in Figure 2, selenium atom Se1 acts as a twofold $\mathrm{ChB}$ donor, through its two sigma-holes, with one very short interaction $(\mathrm{RR}=0.86)$, in the prolongation of the $\mathrm{NC}-\mathrm{Se}(1)$ bond, toward $\mathrm{N} 2 \mathrm{~A}(-\mathrm{x},-\mathrm{y},-\mathrm{z})$, and one longer contact $(\mathrm{RR}=0.93)$, in the prolongation of the $\mathrm{CH}_{2}-\mathrm{Se}(1)$ bond, toward $\mathrm{N} 1(-0.5+\mathrm{x}, 0.5-\mathrm{y}, \mathrm{z})$. On the other hand, selenium

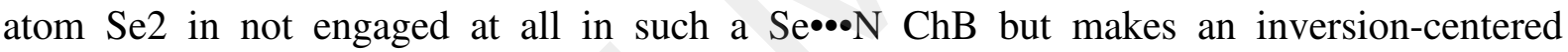
$\operatorname{Se}(2 \mathrm{~A}) \bullet \bullet \operatorname{Se}(2 \mathrm{~A})$ motif (3.391(6) $\AA, \mathrm{RR}=0.89)$ analogous to the so-called type I halogenbonded motifs found in halogenated molecules. This complex behavior contrasts with that found for the less-substituted achiral derivatives such as the bis(selenocyanato) o-, m-, pxylylenes where $\bullet \bullet N C-\mathrm{Se}(\mathrm{R}) \bullet \bullet \mathrm{NC}-\mathrm{Se}(\mathrm{R}) \bullet \bullet$ chains are systematically observed. It probably comes as a consequence of the steric constraint brought by the two extra methyl substituents in anti-1. The situation is different in syn-1. As shown in Figure 3, each of the two selenium atoms acts here as $\mathrm{ChB}$ donor toward the nitrogen atom of the selenocyanate of neighboring molecules, giving the recurrent chains mentioned above, with however larger intermolecular distances $(\mathrm{RR}=0.89,0.95)$ and poorer directionality (the $\mathrm{NC}-\mathrm{Se} \bullet \cdot \mathrm{N}$ angles here are only 162 and $127^{\circ}$ only). 


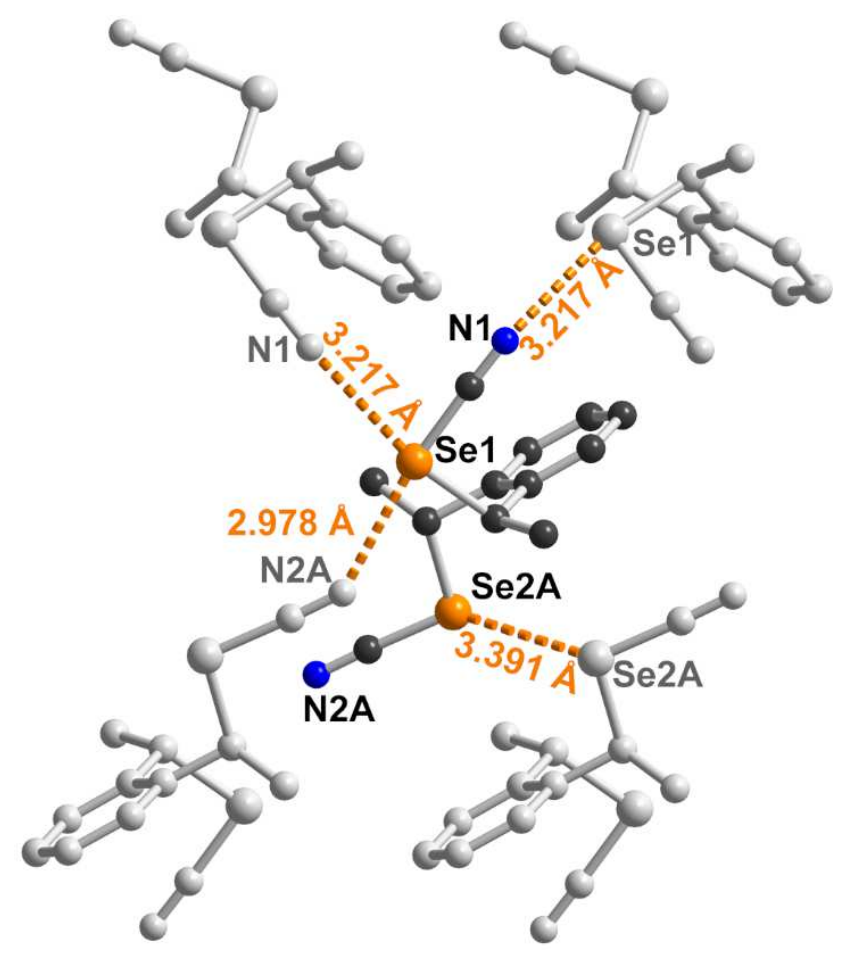

Fig. 2 Details of the ChB interactions in anti-1. Only the major component of the disordered $\mathrm{SeCN}$ group is shown. Relevant bond distances and angles: $\mathrm{Se}(1) \cdots \cdots \mathrm{N}(2 \mathrm{~A})^{\mathrm{i}} 2.978(25) \AA, \mathrm{C}(9-$

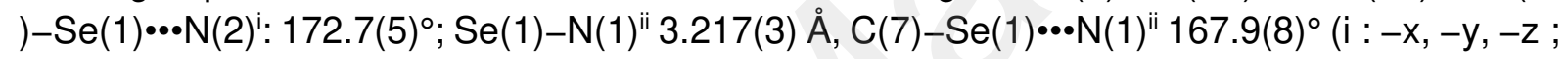
ii : $-0.5+x, 0.5-y, z)$.

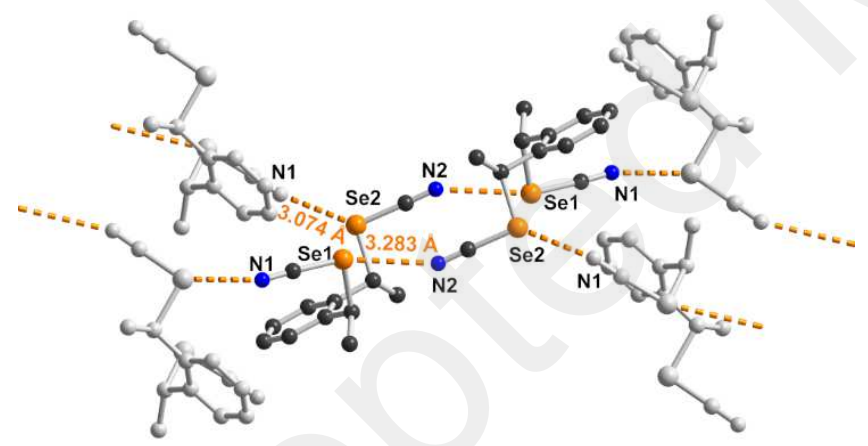

Fig. 3 Details of the $\mathrm{ChB}$ interactions in syn-1. Relevant bond distances and angles: $\operatorname{Se}(1) \cdots N(2)^{i} \quad 3.283(7) \quad \AA, \quad C(9)-\operatorname{Se}(1) \cdots N(2)^{i}: \quad 162.6(2)^{\circ} ; \quad \operatorname{Se}(2) \cdots N(1)^{\mathrm{ii}} \quad 3.074(7) \quad \AA$, $\mathrm{C}(12)-\mathrm{Se}(2)-\mathrm{N}(1) 127.05(25)^{\circ}$ (i : 1-x, -1-y, 1-z ; ii : 1-x, -0.5+y, 0.5-z).

Co-crystal formation with anti-1 was investigated with both neutral Lewis bases such as 4,4'-bipyridine and anionic halide salts such as $\mathrm{Ph}_{4} \mathrm{PX}\left(\mathrm{X}=\mathrm{Cl}^{-}, \mathrm{Br}^{-}, \mathrm{I}^{-}\right)$. With 4,4'bipyridine, co-crystallization afforded a chalcogen-bonded structure of 2:1 stoichiometry formulated as (anti-1) $)_{2}$ (bipy). It crystallizes in the monoclinic system, S.G. P2 $1 / a$ with the 4,4'bipyridine on inversion center, linking the inversion-related enantiomers of anti-1 (Figure 4). Both selenium atoms act here as $\mathrm{ChB}$ donors toward the pyridinic nitrogen atom, with one very short $\mathrm{ChB}$, for $\mathrm{Se}(1) \bullet \bullet \mathrm{N}(3)(\mathrm{RR}=0.87)$ while the $\mathrm{Se}(2) \bullet \bullet \mathrm{N}(3)$ interaction is essentially at van 
der Waals contact distance, with a marked directionality for both interactions as the $\mathrm{NC}-\mathrm{Se} \cdot \bullet \mathrm{N}(3)$ angle amounts to $173.62(13)$ and $168.66(11)^{\circ}$ respectively. Besides, the Se2 selenium atom acts as $\mathrm{ChB}$ donor through its second, weaker $\sigma$-hole located in the prolongation of the $\mathrm{CH}_{2}-\mathrm{Se}$ bond in a Se(2)••^N2 contact while $\mathrm{Se}(1)$ forms an inversion-centered, Type I, Se•••Se motif. Note that the co-crystals formed from 4,4'-bipyridine and the unsubstituted meta- or para- bis(selenocyanato)xylylenes are characterized with notably stronger Se $\bullet \bullet N$ ChB interactions with RR values in the range $0.82-0.84 .^{24 a}$

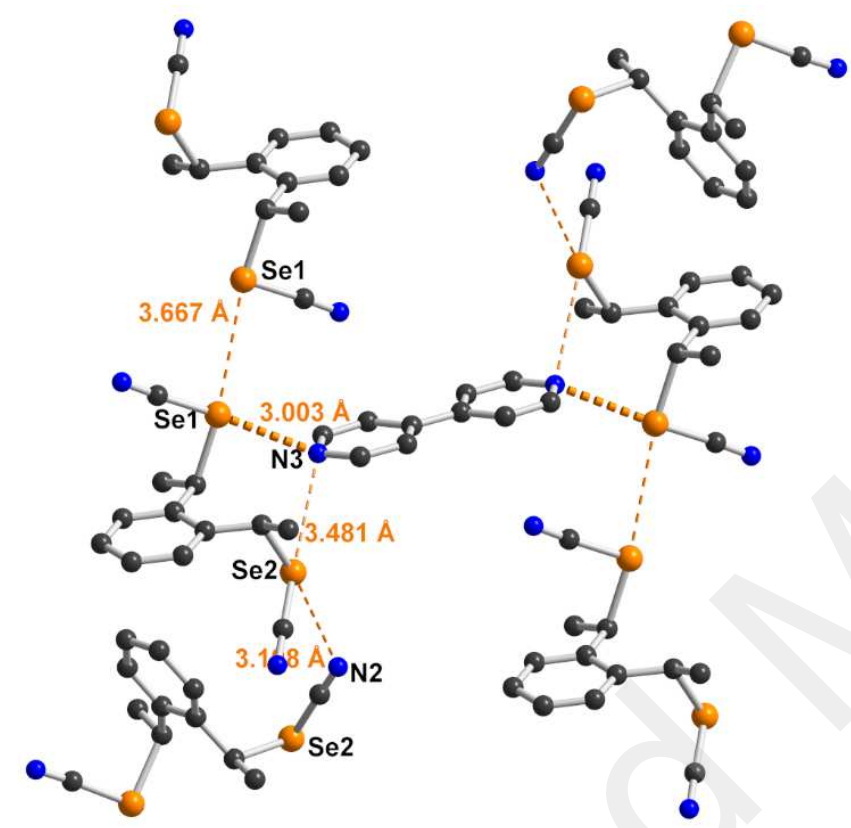

Fig. 4 Detail of the trimolecular adduct between anti-1 and 4,4'-bipyridine. The strongest interaction is highlighted with a thicker dotted line. Relevant bond distances and angles: $\operatorname{Se}(1) \cdots N(3): \quad 3.003(4) \quad \AA, \quad C(9)-\operatorname{Se}(1) \cdots N(3) \quad 173.62(13)^{\circ} ; \quad \operatorname{Se}(2) \cdots N(3) \quad 3.481(3) \quad \AA$, $C(12)-\operatorname{Se}(2) \cdots \cdot N(3) 168.66(11)^{\circ} ; \operatorname{Se}(2) \cdots \cdot N(2)^{i} 3.198(3) \AA, C(11) \cdots \operatorname{Se}(2) \cdots \cdot N(2)^{i} 141.06(8)^{\circ}$; $\mathrm{Se}(1) \cdots \operatorname{Se}(1)^{\mathrm{ii}} 3.667(1)$ (i: 0.5+x, 0.5-y, z ; ii: $-\mathrm{x},-\mathrm{y}, 2-\mathrm{z}$ ).

Co-crystals of anti-1 with the three tetraphenyl phosphonium halides, i.e. $\mathrm{Ph}_{4} \mathrm{PCl}$, $\mathrm{Ph}_{4} \mathrm{PBr}$ and $\mathrm{Ph}_{4} \mathrm{PI}$, all crystallize in a 1:1 stoichiometry with the halide in a $\mu_{2}$ environment, chelated by the ditopic $\mathrm{ChB}$ donor. The chloride and bromide salts are isostructural, and crystallize as $\mathrm{Et}_{2} \mathrm{O}$ solvate in the triclinic system, S. G. $P \overline{1}$, with the anionic complex in general position. As shown in Figures 5a-5b, the environment of the $\mathrm{Cl}^{-}$and $\mathrm{Br}^{-}$anions is distorted

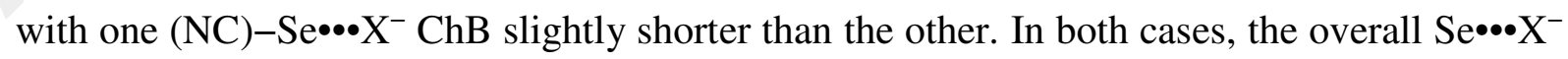
distance corresponds to a reduction ratio (considering the ionic radius of the halide rather than its van der Waal radius, i.e. $\mathrm{Cl}^{-}: 1.81 \AA, \mathrm{Br}^{-}: 1.96 \AA, \mathrm{I}^{-}: 2.20 \AA$ ) in the range $0.88-0.90$. These 
values are notably larger than those reported earlier in the unsubstituted achiral analogs chelating $\mathrm{Cl}^{-}$or $\mathrm{Br}^{-}$anions which exhibit $\mathrm{RR}$ values as small as $0.84 .{ }^{25}$

The situation is more complex in the iodide adduct (Figure 5c). It crystallizes without solvent in the orthorhombic system, space group $P 2{ }_{1} 2_{1} 2_{1}$, with the anionic complex in general position. The Se•••I- distances are here associated with RR values of $0.88-0.89$ and one $(\mathrm{N}) \mathrm{C}-\mathrm{Se} \bullet \bullet \mathrm{I}-$ angle deviates notably from $180^{\circ}\left(167^{\circ}\right)$.
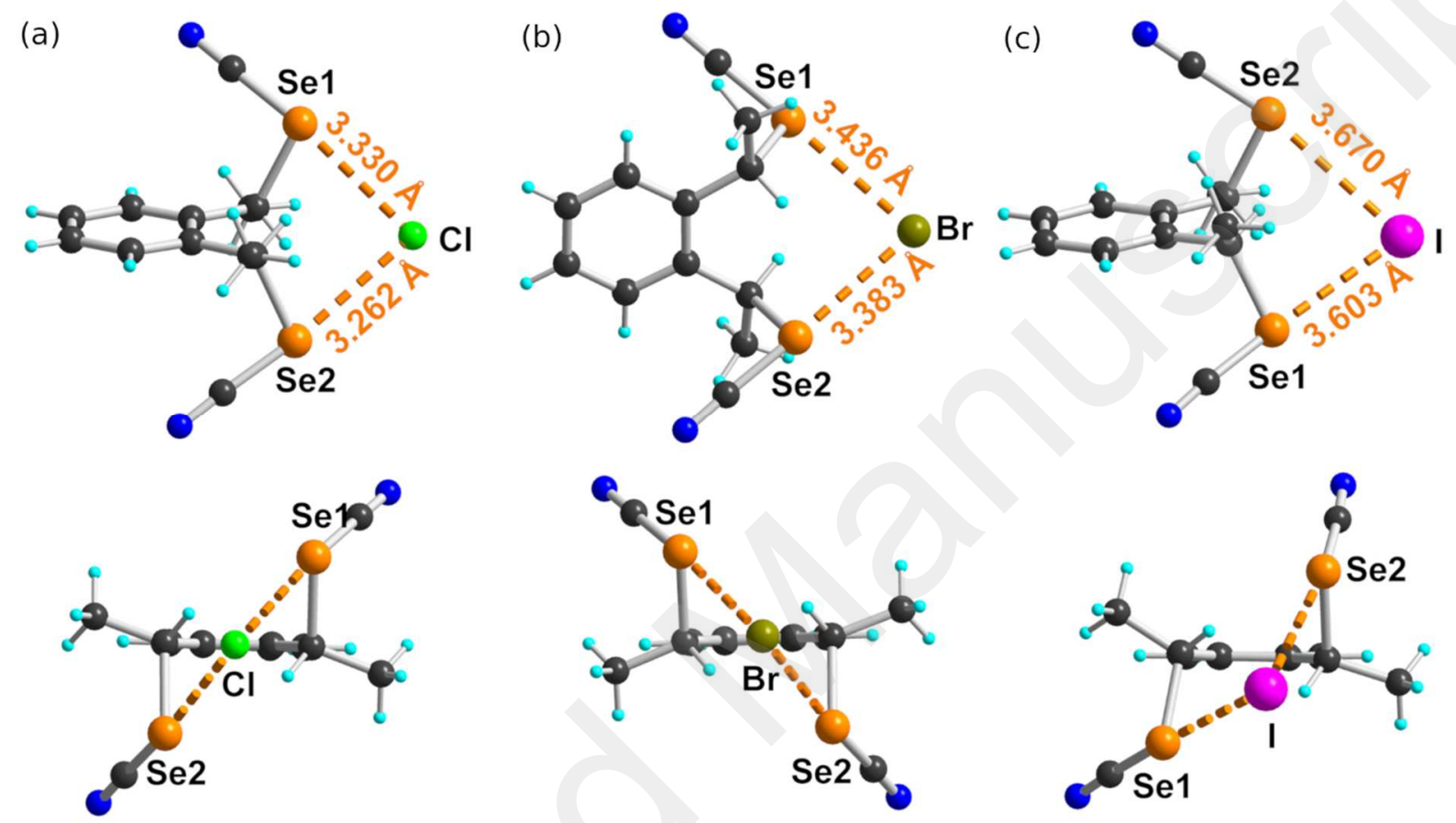

Fig. 5 Detail of the three halide adducts with structural characteristics in: (a) $\mathrm{Ph}_{4} \mathrm{P}^{+}[($anti1) $\left.\mathrm{Cl}^{-}\right] \cdot\left(\mathrm{Et}_{2} \mathrm{O}\right)_{0.5}, \quad$ (b) $\mathrm{Ph}_{4} \mathrm{P}^{+}\left[\left(\right.\right.$anti-1) $\left.\mathrm{Br}^{-}\right] \cdot\left(\mathrm{Et}_{2} \mathrm{O}\right)_{0.5}$, and (c) $\mathrm{Ph}_{4} \mathrm{P}^{+}\left[\left(\right.\right.$anti-1) $\left.\mathrm{I}^{-}\right]$. Relevant bond distances and angles: $\mathrm{Se}(1) \cdots \mathrm{Cl}$ : $3.330(7) \AA$, $(\mathrm{N}) \mathrm{C}-\mathrm{Se}(1) \cdots \mathrm{Cl}: 173.75(13)^{\circ}, \mathrm{Se}(2) \cdots \mathrm{Cl}$ :

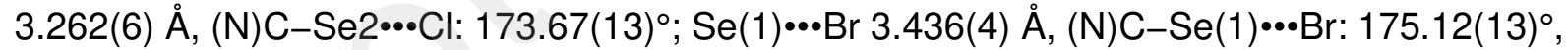

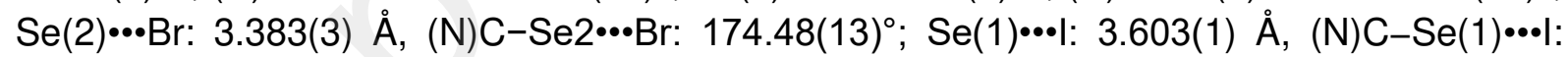

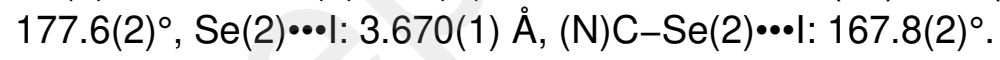

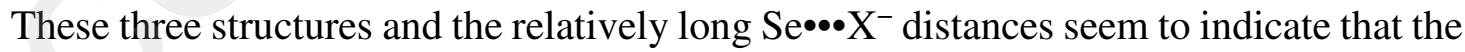
introduction of the methyl substituents on the benzylic positions induces, in the anti-isomer at least, an unfavorable effect on the $\mathrm{ChB}$ donor ability of this chelating system. At first sight, this effect might have two origins, (i) the electron-donating effect of the methyl groups might decrease the overall $\mathrm{ChB}$ donor ability of the selenium atoms, and/or (ii) the steric constraints brought by the methyl groups do not favor the optimal "coordination" of the halide anion, at least in the anti conformation of the chelate.

One first element of answer can be already found in the crystal structure obtained from the association of $\mathrm{Et}_{4} \mathrm{NCl}$ and the syn isomer, using a syn-enriched sample. A 2:1 association 
formulated as $\left(\mathrm{Et}_{4} \mathrm{~N}^{+}\right)\left[(\operatorname{syn}-\mathbf{1})_{2} \mathrm{Cl}^{-}\right]$is indeed isolated, which crystallizes in the monoclinic system, S. G. $P 2{ }_{1} / a$, with the $\mathrm{Cl}^{-}$anion on inversion center in a $\mu_{4}$, square-planar environment (Figure 6). The Se•••Cl- distances are very short $(3.11,3.16 \AA$, $\mathrm{RR}=0.84-0.85)$, and furthermore even shorter than those reported in the chloride adduct of the achiral chelating ortho-bis(selenocyanate)xylylene A (3.17-3.20 $\AA, \mathrm{RR}=0.85-0.86)$ or the $1,2,4,5$ tetrakis(selenocyanoatomethyl)benzene $\mathrm{E}(3.16-3.22 \AA$, $\mathrm{RR}=0.85-0.87) .{ }^{25}$

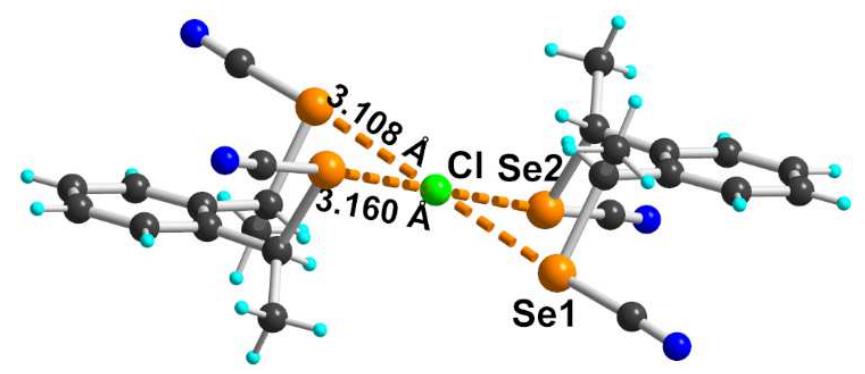

Fig. 6 Detail of the anionic moiety $\left[(s y n-1)_{2} \mathrm{Cl}^{-}\right]$in its $\mathrm{Et}_{4} \mathrm{~N}^{+}$salt. Relevant bond distances and angles: $\mathrm{Se}(1) \cdots \mathrm{Cl}: 3.108(3) \AA \mathrm{A}, \mathrm{C}-\mathrm{Se}(1) \cdots \mathrm{Cl}$ : $176.2(2)^{\circ}$; Se(2) ${ }^{\circ} \mathrm{Cl}: 3.160(1) \AA, \mathrm{C}-\mathrm{Se}(2) \cdots \mathrm{Cl}$ : $176.0(3)^{\circ}$.

In order to rationalize these differences, theoretical calculations of the relative energies of the molecules (anti vs. syn) and their $\mathrm{Cl}^{-}$adducts were performed. Total energy for the syn and anti forms of 1 was calculated [B3LYP 6-311++G(d,p)] after geometry optimization, keeping the $\mathrm{C}_{2}$ geometry of the anti form, and the $\mathrm{C}_{\mathrm{s}}$ geometry of the syn form (Figure 7). Under these conditions, the anti form is more stable by $2.31 \mathrm{kcal} / \mathrm{mol}(9.7 \mathrm{~kJ} / \mathrm{mol})$ than the $s y n$ form. Without symmetry constraints, the syn form is able to stabilize through an intramolecular Se••Se ChB interaction (3.958 $\mathrm{A})$ reducing the difference to $0.68 \mathrm{kcal} / \mathrm{mol}(2.8 \mathrm{~kJ} / \mathrm{mol})$.

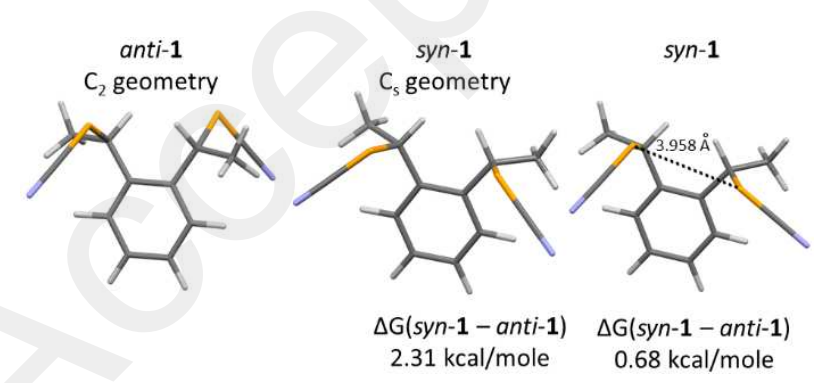

Fig. 7 Optimized geometries of anti-1 and syn-1 with and without symmetry constraints.

The evolution of the $\sigma$-hole amplitude has been determined for three molecules bearing, either a methyl group on each benzylic carbon (that is in anti-1 and syn-1), or a hydrogen atom (that is the unsubstituted molecule A in scheme 1), or, for comparison purposes, a fluorine atom 
(instead of a methyl group) in the fluorine-substituted derivatives of A, that is anti-3 and syn3. As shown in Figure 8a, we note a very small difference between anti-1 and syn-1, with $\mathrm{V}_{\mathrm{s}, \max }$ values of 46.26 and $47.05 \mathrm{kcal} / \mathrm{mol}$ respectively, i.e. a slightly larger $\mathrm{V}_{\mathrm{s}, \max }$ value for syn-1. Such a small difference cannot explain the much shorter $\mathrm{ChB}$ interaction experienced with the $\mathrm{Cl}^{-}$anion with syn-1 (See above). The evolution in the series of substituents $\mathrm{Me}_{2} / \mathrm{H}_{2} / \mathrm{F}_{2}$ follows the expected trend, with a strengthening of the $\mathrm{V}_{\mathrm{s}, \max }$ in the order $\mathrm{F}_{2}>\mathrm{H}_{2}>\mathrm{Me}_{2}$ associated with the electron withdrawing effect of the fluorine atoms. Furthermore, an even stronger electropositive area $\left(54.3 \mathrm{kcal} \mathrm{mol}^{-1}\right)$ is identified in the fluorine substituted syn-3 in-between the two activated benzylic hydrogen atoms located $\alpha$ to the fluorine atoms. These calculations demonstrate that, whatever the substituents, the syn form exhibits systematically a slightly stronger $\sigma$-hole than the anti form. However, they are unable to explain the much shorter $\mathrm{ChB}$ interaction with $\mathrm{Cl}^{-}$.
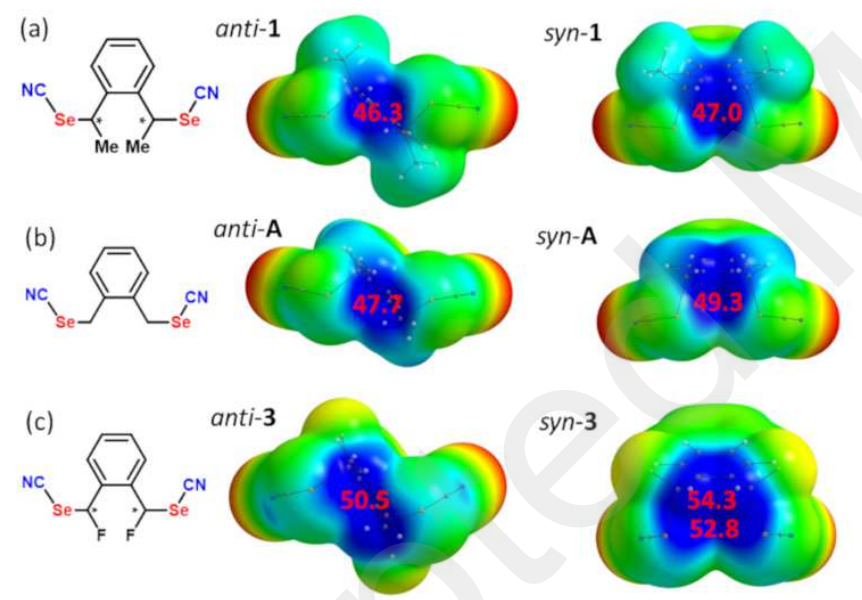

Fig. 8 Details of the ESP maps of (a) methyl-substituted anti-1 and syn-1, (b) unsubstituted A and (c) fluorine-substituted anti-3 and syn-3, at optimized geometries, plotted on the 0.001 electron/bohr ${ }^{3}$ isosurface of the electronic density. The extrema values $\mathrm{V}_{\mathrm{s}, \max }(\mathrm{kcal} / \mathrm{mol})$ of the electropositive (blue) area are indicated in red numbers. Potential scale ranges from -25.1 $\mathrm{kcal} / \mathrm{mol}$ (red) to $+37.7 \mathrm{kcal} / \mathrm{mol}$.

Calculations performed on 1:1 adducts between the syn and anti forms of $\mathbf{1}$ and a chloride anion give geometries very close to those observed in the crystal structures of $\mathrm{Ph}_{4} \mathrm{P}^{+}[($anti1) $\left.\mathrm{Cl}^{-}\right] \bullet\left(\mathrm{Et}_{2} \mathrm{O}\right)_{0.5}$ and $\mathrm{Et}_{4} \mathrm{~N}^{+}\left[(\text {syn-1 })_{2} \mathrm{Cl}^{-}\right]$(Figure 9). The notably shorter $\mathrm{Se} \bullet \bullet \mathrm{Cl}^{-}$distances with syn-1 (3.11-3.16 $\AA$, vs. 3.26-3.33 $\AA$ with anti-1) is very well reproduced by the calculations which give a Se $\bullet \cdot \mathrm{Cl}^{-}$distance at $3.139 \AA$ in $s y n-1 \cdot \mathrm{Cl}^{-}$adduct $\left(\mathrm{C}_{\mathrm{s}}\right.$ geometry), notably smaller 
indeed than the $3.210 \AA$ distance calculated in anti-1・Cl${ }^{-}$adduct $\left(\mathrm{C}_{2}\right.$ geometry). The overall energy of both adducts is almost the same with $\Delta \mathrm{G}\left(\operatorname{syn}-\mathbf{1} \cdot \mathrm{Cl}^{-}-\right.$anti-1 $\left.\cdot \mathrm{Cl}^{-}\right)=1.29 \mathrm{kcal} / \mathrm{mole}$, that is a slightly more stable adduct with anti-1. On the other hand, the BSSE complexation energy $\left(-35.36 \mathrm{kcal} / \mathrm{mole}\right.$ for anti-1. $\mathrm{Cl}^{-},-35.55 \mathrm{kcal} / \mathrm{mol}$ for $\left.s y n-\mathbf{1} \cdot \mathrm{Cl}^{-}\right)$gives a small advantage to the syn adduct. It appears therefore that the shorter $\mathrm{Se} \cdot \bullet^{-\mathrm{Cl}^{-}} \mathrm{ChB}$ interaction experienced with the syn-1 $\mathrm{ChB}$ donor is not associated with a sizeable stabilization of this chloride adduct, when compared with its anti analog. As shown in Figure 8, the electropositive area (in blue) interacting with $\mathrm{Cl}^{-}$exceeds that delineated with the selenium atoms only and include also the two benzylic hydrogen atoms. The overall interactions in both adducts thus implies also $\mathrm{C}_{\mathrm{Bz}}-\mathrm{H} \cdot \bullet^{-} \mathrm{Cl}^{-}$contacts, whose geometrical features (for both experimental and calculated structures) are collected in Table 1 . These contacts are quite short (2.79-2.86 $\AA$ for a contact distance of 3.01) $\AA$ even if they deviate notably from linearity $\left(\mathrm{C}-\mathrm{H}^{\circ} \cdot \mathrm{Cl}^{-}\right.$angles in the range $123-128^{\circ}$ ). Their contribution to the overall stabilization of the adducts can probably not be omitted.

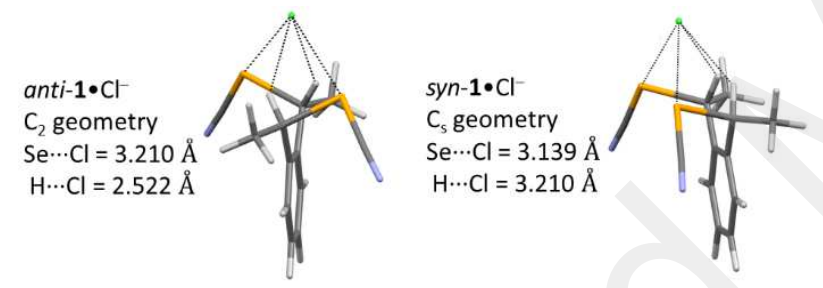

Fig. 9 Optimized geometries of the anti-1. $\mathrm{Cl}^{-}$and syn-1. $\mathrm{Cl}^{-}$adducts with indicated symmetry constraints.

Table 1 Structural characteristics of $\mathrm{C}-\mathrm{H} \cdot \cdots \mathrm{Cl}^{-}$contacts, from X-ray crystal structures of $\mathrm{Ph}_{4} \mathrm{P}^{+}\left[\left(\right.\right.$anti-1) $\left.\mathrm{Cl}^{-}\right] \cdot\left(\mathrm{Et}_{2} \mathrm{O}\right)_{0.5}$ and $\mathrm{Et}_{4} \mathrm{~N}^{+}\left[(\text {syn-1 })_{2} \mathrm{Cl}^{-}\right]$and from theoretical calculations on $1: 1$ adducts (in italics).

\begin{tabular}{cccc}
\hline & & $\mathrm{H} \bullet \bullet \mathrm{Cl}^{-}$dist $(\AA)$ & $\mathrm{C}-\mathrm{H} \bullet \bullet \mathrm{Cl}-$ ang. $\left(^{\circ}\right)$ \\
\hline (anti-1)Cl & X-ray & $2.863(6)$ & $128.1(2)$ \\
& & $2.800(4)$ & $127.0(2)$ \\
& calcd. & 2.522 & 138.1 \\
$($ syn-1)Cl & X-ray & $2.794(2)$ & $125.2(3)$ \\
& & $2.811(2)$ & $123.0(4)$ \\
& \multirow{2}{*}{ calcd. } & 2.573 & 134.9 \\
\hline
\end{tabular}




\section{Conclusions}

Introduction of methyl substituents on the achiral 1,2-bis(selenocyanatomethyl)benzene (A) leads to diastereoisomers of a novel chelating, chiral ChB donor, namely 1,2-bis(1selenocyanatoethyl)benzene (1), as a mixture of the two anti enantiomers and the syn (meso) form. The anti (racemic) mixture was isolated in a pure form by recrystallization. We were able to isolate crystals of both anti-1 and syn-1. Structure determinations show the recurrent formation of short Se $\bullet \bullet \mathrm{N} \equiv \mathrm{C} \mathrm{ChB}$ interactions $(\mathrm{RR}=0.88-0.95)$. Co-crystallization of anti-1 with 4,4'-bipyridine affords a 2:1 adduct, i.e. (anti-1) $)_{2}$ (bipy), with one very short $\mathrm{Se} \bullet \bullet \mathrm{N}_{\mathrm{Py}} \mathrm{ChB}$ at $3.003 \AA(\mathrm{RR}=0.87)$. Co-crystallization of anti-1 with tetraphenylphosphonium halides $\left(\mathrm{Cl}^{-}\right.$, $\mathrm{Br}^{-}, \mathrm{I}^{-}$) provides the 1:1 adducts while a 2:1 adduct is isolated between syn-1 and $\mathrm{Et}_{4} \mathrm{NCl}$, formulated as $\mathrm{Et}_{4} \mathrm{~N}^{+}\left[(\operatorname{syn}-\mathbf{1})_{2} \mathrm{Cl}^{-}\right]$. Comparison of chloride chelation with anti-1 and syn-1 shows much shorter (NC)Se $\bullet \cdot \mathrm{Cl}^{-} \mathrm{ChB}$ interactions with the syn isomer. Calculations of (i) the electrostatic surface potential of neutral $\mathrm{ChB}$ donors for $\sigma$-hole amplitude determination and (ii) the $\mathrm{Cl}^{-} \mathrm{BSSE}$ complexation energy cannot explain these differences even if the geometry optimizations well reproduce them. Besides, the concomitant contribution of $\mathrm{C}-\mathrm{H} \cdot \bullet \mathrm{Cl}^{-}$ hydrogen bonds involving benzylic hydrogen atoms $\alpha$ to the $\mathrm{SeCN}$ moieties is highlighted. Altogether, the notably shorter Se $\bullet^{\bullet} \mathrm{Cl}^{-}$distances found with the syn isomer appear to be a mere consequence of the overall relative orientation of both selenocyanate moieties together with contribution of $\mathrm{C}_{\mathrm{Bz}}-\mathrm{H} \bullet \bullet \mathrm{Cl}^{-}$hydrogen bonds, as illustrated by the broader spatial expansion of the electropositive area observed in the syn isomer. This modulation of the ChB donor ability, combined with the introduction of chirality, provides novel chelating $\mathrm{ChB}$ donors which will be of interest in crystal engineering, anion recognition processes and catalysis. We are pursuing our works along these lines.

\section{Experimental section}

\section{General remarks}

NMR spectra were recorded at room temperature using $\mathrm{CDCl}_{3}$ unless otherwise noted. Chemical shifts are reported in ppm and ${ }^{1} \mathrm{H}$ NMR spectra were referenced to residual $\mathrm{CHCl}_{3}$ (7.26 ppm) and ${ }^{13} \mathrm{C}$ NMR spectra were referenced to $\mathrm{CHCl}_{3}(77.2 \mathrm{ppm})$. All reagents are commercially available and were used without further purification. Melting points were measured on a Kofler hot-stage apparatus and are uncorrected. Elemental analysis were performed at BioCIS laboratory, UMR-8076-CNRS-University Paris-Saclay. All the reactions 
were performed under an argon atmosphere. Methanol, acetonitrile and dichloromethane were dried using inert pure solvent column device.

\section{Syntheses}

1,2-bis(1-bromoethyl)benzene 2. In a $100 \mathrm{~mL}$ two-neck round-bottom flask equipped with condenser, 1,2-diethylbenzene ( $2 \mathrm{~g}, 14.9 \mathrm{mmol})$ and NBS (5.3 g, 29 mmol, 2 eq.) are dissolved in $\mathrm{CCl}_{4}(30 \mathrm{~mL})$ and warmed to reflux. After addition of a little AIBN, stirring is maintained for 30 minutes. Another small quantity of AIBN is added again. After an hour of stirring and cooling, the succinimide is eliminated by filtration. The filtrate is evaporated and the solid residue filtered through a silica column with petroleum ether as eluant. Evaporation of the solvent yields 2 as a white solid (2.93 g, 67\%), in a ratio anti/syn of 70:30 (based on ${ }^{1} \mathrm{H}$ NMR). Pure anti-2 is obtained by recrystallization in hexane, while the mother liquors are enriched in syn isomer in a ratio anti/syn of 23:77.

anti-2 m. p. $89^{\circ} \mathrm{C}^{1}{ }^{1} \mathrm{H}$ NMR $\left(300 \mathrm{MHz}, \mathrm{CDCl}_{3}\right) \delta 2.15\left(6 \mathrm{H}, \mathrm{d}, J^{3}=6.84 \mathrm{~Hz}\right) ; 5.71\left(2 \mathrm{H}, \mathrm{q}, J^{3}=\right.$ 6.84); 7.34-7.40 (2H, m); 7.58-7.63 (2H, m)

syn-2 ${ }^{1} \mathrm{H}$ NMR $\left(300 \mathrm{MHz}, \mathrm{CDCl}_{3}\right) \delta 2.10\left(6 \mathrm{H}, \mathrm{d}, J^{3}=6.90 \mathrm{~Hz}\right) ; 5.61\left(2 \mathrm{H}, \mathrm{q}, J^{3}=6.90\right) ; 7.32-$ $7.38(2 \mathrm{H}, \mathrm{m}) ; 7.58-7.63(2 \mathrm{H}, \mathrm{m})$.

1,2-bis(1-selenocyanatoethyl)benzene 1. To a solution of anti-2 $(0.59 \mathrm{~g}, 2 \mathrm{mmol})$ dissolved in acetone $(5 \mathrm{~mL})$ at room temperature, $\mathrm{KSeCN}(0.87 \mathrm{~g}, 6 \mathrm{mmol}, 3 \mathrm{eq}$.) dissolved in warm acetone $(5 \mathrm{~mL})$ is added dropwise over a period of 10 minutes. After 30 minutes of stirring, the suspension is filtered, the filtrate is evaporated, and the resulting solid dissolved in $\mathrm{CH}_{2} \mathrm{Cl}_{2}(10 \mathrm{~mL})$ and washed with water $(2 \times 10 \mathrm{~mL})$. The organic layers are collected, dried with $\mathrm{MgSO}_{4}$, filtered and evaporated to give $\mathbf{1}(0.59 \mathrm{~g}, 86 \%)$ as a white solid in a ratio anti/syn of 76:24 (based on NMR). Pure sample of anti-1 is obtained from recrystallization in acetone. The same reaction performed with $\mathbf{2}$ in a anti/syn ratio of 23:77 afforded $\mathbf{1}$ in a anti/syn ratio of $66: 34$

anti-1: M. p. $113^{\circ} \mathrm{C} ;{ }^{1} \mathrm{H}$ NMR $\left(300 \mathrm{MHz}, \mathrm{CDCl}_{3}\right) \delta 2.12\left(6 \mathrm{H}, \mathrm{d}, J^{3}=6.9 \mathrm{~Hz}\right) ; 5.25\left(2 \mathrm{H}, \mathrm{q}, J^{3}\right.$ = 6.9); 7.40-7.45 (2H, m); 7.54-7.59 (2H, m). ${ }^{13} \mathrm{C} \mathrm{NMR:} 22.58\left(\mathrm{CH}_{3}\right) ; 40.00\left(\underline{\mathrm{C}} \mathrm{H}-\mathrm{CH}_{3}\right) ; 101.86$; 127.24; 129.65, 137.06. Elem. Anal. Calcd. for $\mathrm{C}_{12} \mathrm{H}_{12} \mathrm{~N}_{2} \mathrm{Se}_{2}$ : C, 42.12; H, 3.54; N, 8.19; found: C, 41.92; H, 3.57; N, 8.20. Mother liquors are enriched in syn compound with a syn:anti distribution of 67:33. Their dissolution in acetone and diffusion of hexane afforded a few crystals of syn-1 suitable for X-ray diffraction. syn-1: ${ }^{1} \mathrm{H}$ NMR $\left(300 \mathrm{MHz}, \mathrm{CDCl}_{3}\right) \delta 2.15(6 \mathrm{H}$, 
$\left.\mathrm{d}, J^{3}=6.90 \mathrm{~Hz}\right) ; 5.17\left(2 \mathrm{H}, \mathrm{q}, J^{3}=6.90\right) ; 7.40-7.45(2 \mathrm{H}, \mathrm{m}) ; 7.54-7.59(2 \mathrm{H}, \mathrm{m}) .{ }^{13} \mathrm{C} \mathrm{NMR}: 24.03$ $\left(\mathrm{CH}_{3}\right) ; 40.11\left(\underline{\mathrm{CH}}-\mathrm{CH}_{3}\right) ; 101.97 ; 127.58 ; 129.69,136.84$.

(anti-1)2(4,4'-bipy). In a small test tube, 4,4'-bipyridine (10 mg, $0.06 \mathrm{mmol})$ and anti$1(11 \mathrm{mg}, 0.03 \mathrm{mmol})$ are dissolved in acetone $(1 \mathrm{~mL})$. Diffusion of $\mathrm{Et}_{2} \mathrm{O}$ vapors affords after 5 days colorless crystals of (anti-1) $)_{2}\left(4,4\right.$ '-bipy). Elem. Anal. Calcd. for $\mathrm{C}_{34} \mathrm{H}_{32} \mathrm{~N}_{6} \mathrm{Se}_{4}$ : C, 48.59; H, 3.84; N, 10.00; found: C, 48.57; H, 3.91; N, 9.95.

$\mathbf{P h}_{4} \mathbf{P C l}\left(\right.$ anti-1) $\bullet\left(\mathbf{E t}_{2} \mathbf{O}\right)_{0.5}$ In a small tube, anti-1 $(11 \mathrm{mg}, 0.03 \mathrm{mmol})$ and $\mathrm{Ph}_{4} \mathrm{PCl}(13.5$ $\mathrm{mg}, 0.036 \mathrm{mmol}$,) were dissolved in acetonitrile $(1 \mathrm{~mL})$. The tube was placed into a small bottle with ether for diffusion crystallization. Crystals were isolated after 5 days. Exact composition was deduced from X-ray diffraction. Elem. Anal. Calc. for $\mathrm{C}_{36} \mathrm{H}_{32} \mathrm{ClN}_{2} \mathrm{PSe}_{2}$ (without $\mathrm{Et}_{2} \mathrm{O}$ ): C, 60.3; H, 4.5; N, 3.91; found: C, 56.21; H, 4.62; N, 4.20.

$\operatorname{Ph} 4 \mathbf{P B r}($ anti-1)•(Et 20 ) 0.5 In a small tube, anti-1 (10 mg, $0.03 \mathrm{mmol})$ and $\mathrm{Ph}_{4} \mathrm{PBr}(17.7$ $\mathrm{mg}, 0.042 \mathrm{mmol}$ ) were dissolved in $1 \mathrm{~mL}$ of acetonitrile. The tube was placed into a small bottle with ether for diffusion crystallization. Crystals were isolated after 5 days. Exact composition was deduced from X-ray diffraction. Elem. Anal. Calcd. for $\mathrm{C}_{36} \mathrm{H}_{32} \mathrm{BrN}_{2} \mathrm{PSe}_{2}$ (without $\mathrm{Et} 2 \mathrm{O}$ ): C, 56.78; H, 4.24; N, 3.68; found: C, 56.98; H, 4.71; N, 2.34 .

Ph4PI(anti-1). In a small tube, anti-1 (13 mg, 0.04 mmol, 1 equiv) and $\mathrm{Ph}_{4} \mathrm{PI}(21 \mathrm{mg}$, $0.045 \mathrm{mmol}, 1$ equiv) were dissolved in $1 \mathrm{~mL}$ of acetonitrile. The tube was put into a small bottle with ether for diffusion crystallization. Crystals were isolated after 5 days. Elem. Anal. Calcd. for $\mathrm{C}_{36} \mathrm{H}_{32} \mathrm{IN}_{2} \mathrm{PSe}_{2}$ : C, 53.48; H, 3.99; N, 3.47; found: C, 54.43; H, 4.02; N, 3.42.

Et4NCl(syn-1)2. In a small tube, a 67/33 mixture of syn-1/anti-1 (10 mg, $0.03 \mathrm{mmol})$ and $\mathrm{Et}_{4} \mathrm{NCl}(4.9 \mathrm{mg}, 0.03 \mathrm{mmol})$ were dissolved in acetone $(1 \mathrm{~mL})$. The tube was placed into a small closed bottle with hexane for diffusion crystallization. Crystals were isolated after 5 days. Elem. Anal. Calcd. for $\mathrm{C}_{32} \mathrm{H}_{44} \mathrm{ClN}_{5} \mathrm{Se}_{4}$ : C, 45.22; H, 5.22; N, 8.24; found: C, 44.88; H, 6.13; N, 7.97.

Crystallography Details of the structural analyses for the eight compounds are summarized in Table 2. Single crystals were coated with Paratone-N oil and mounted on a MicroMount loop. The crystallographic data were collected at 296(2)K on a Bruker AXS APEX II diffractometer with Mo-K $\alpha$ radiation $(\lambda=0.71073 \AA$ ) for all compounds except anti-1 and anti-2 which were collected on a Bruker AXS D8 Venture diffractometer equipped with a Mo-K $\alpha$ microsource and a PHOTON 100 detector at 150(2) K. The structures were solved by dual-space algorithm using SHELXT programs ${ }^{33}$ and then refined with full-matrix least-squares methods based on 
$\mathrm{F}^{2}$ (SHELXL-2014) $)^{34}$ with the aid of the WinGX program. ${ }^{35}$ All non-hydrogen atoms were refined with anisotropic atomic displacement parameters. Crystallographic data have been deposited with Cambridge Crystallographic Data Centre, CCDC: 2040289-2040296.

Table 2 Crystallographic data

\begin{tabular}{|c|c|c|c|c|}
\hline Compound & anti-1 & syn-1 & anti-2 & $(\text { anti-1) })_{2} \bullet$ bipy \\
\hline Formula & $\mathrm{C}_{12} \mathrm{H}_{12} \mathrm{~N}_{2} \mathrm{Se}_{2}$ & $\mathrm{C}_{12} \mathrm{H}_{12} \mathrm{~N}_{2} \mathrm{Se}_{2}$ & $\mathrm{C}_{10} \mathrm{H}_{12} \mathrm{Br}_{2}$ & $\mathrm{C}_{17} \mathrm{H}_{16} \mathrm{~N}_{3} \mathrm{Se}_{2}$ \\
\hline $\mathrm{FW}\left(\mathrm{g} \cdot \mathrm{mol}^{-1}\right)$ & 342.16 & 342.16 & 292.02 & 420.25 \\
\hline Crystal system & monoclinic & monoclinic & monoclinic & monoclinic \\
\hline Space group & $P 2{ }_{1} / a$ & $P 2_{1} / n$ & $P 2{ }_{1} / n$ & $P 2_{1} / a$ \\
\hline$a(\AA)$ & $7.5686(4)$ & $8.5502(6)$ & $8.2203(8)$ & $7.1221(4)$ \\
\hline$b(\AA)$ & $21.7486(11)$ & $7.0090(4)$ & $14.6643(16)$ & $28.6165(13)$ \\
\hline$c(\AA)$ & $8.2075(4)$ & $22.6261(15)$ & $9.4380(9)$ & $8.6600(5)$ \\
\hline$\alpha\left(^{\circ}\right)$ & 90.00 & 90.00 & 90.00 & 90.00 \\
\hline$\beta\left({ }^{\circ}\right)$ & $105.783(2)$ & $90.121(3)$ & $110.312(3)$ & $105.763(2)$ \\
\hline$\gamma\left(\left(^{\circ}\right)\right.$ & 90.00 & 90.00 & 90.00 & 90.00 \\
\hline$V\left(\AA^{3}\right)$ & $1300.07(11)$ & $1355.94(15)$ & 1066.96(19) & $1698.62(16)$ \\
\hline$T(\mathrm{~K})$ & $150(2)$ & $296(2)$ & $150(2)$ & $296(2)$ \\
\hline Cryst. $\operatorname{dim} .\left(\AA^{3}\right)$ & $0.16 \times 0.12 \times 0.05$ & $0.23 \times 0.17 \times 0.02$ & $0.12 \times 0.09 \times 0.02$ & $0.26 \times 0.21 \times 0.18$ \\
\hline$Z$ & 4 & 4 & 4 & 4 \\
\hline$D_{\text {calc }}\left(\mathrm{g} \cdot \mathrm{cm}^{-3}\right)$ & 1.748 & 1.676 & 1.818 & 1.643 \\
\hline$\mu\left(\mathrm{mm}^{-1}\right)$ & 5.663 & 5.429 & 7.544 & 4.353 \\
\hline Abs. corr. & multi-scan & multi-scan & multi-scan & multi-scan \\
\hline $\mathrm{T}_{\min }, \mathrm{T}_{\max }$ & $0.447,0.753$ & $0.344,0.897$ & $0.447,0.860$ & $0.347,0.457$ \\
\hline Total refls. & 20013 & 22207 & 19035 & 12513 \\
\hline Uniq. refls. $\left(R_{\mathrm{int}}\right)$ & $2993(0.0572)$ & $3062(0.0753)$ & $2439(0.0571)$ & $3912(0.0291)$ \\
\hline $\begin{array}{l}\text { Unique refls. } \\
(\mathrm{I}>2 \mathrm{~s}(\mathrm{I}))\end{array}$ & 2631 & 1862 & 1943 & 3041 \\
\hline$R_{1}$ & 0.027 & 0.0495 & 0.0220 & 0.0367 \\
\hline$w R_{2}$ (all data) & 0.066 & 0.1128 & 0.0513 & 0.0717 \\
\hline GoF & 1.067 & 1.076 & 1.052 & 1.085 \\
\hline Res. dens $\left(\mathrm{e}^{-} \AA^{-3}\right)$ & $0.50,-0.65$ & $0.41,-0.52$ & $0.43,-0.78$ & $0.39,-0.64$ \\
\hline
\end{tabular}


Table 2 (continued)

\begin{tabular}{|c|c|c|c|c|}
\hline Compound & $\begin{array}{c}\mathrm{Ph}_{4} \mathrm{PCl}(\text { anti-1 }) \\
\bullet 0.5 \mathrm{Et}_{2} \mathrm{O}\end{array}$ & $\begin{array}{c}\mathrm{Ph}_{4} \mathrm{PBr}(\text { anti-1 }) \\
\cdot 0.5 \mathrm{Et}_{2} \mathrm{O}\end{array}$ & $\mathrm{Ph}_{4} \mathrm{PI}($ anti-1) & $\mathrm{Et}_{4} \mathrm{NCl}(\text { syn-1 })_{2}$ \\
\hline \multicolumn{5}{|l|}{$\mathrm{CCDC}$} \\
\hline \multirow{2}{*}{ Formula } & $\mathrm{C}_{38} \mathrm{H}_{37} \mathrm{ClN}_{2} \mathrm{O}_{0.50}$ & $\mathrm{C}_{38} \mathrm{H}_{37} \mathrm{BrN}_{2} \mathrm{O}_{0.50}$ & \multirow{2}{*}{$\mathrm{C}_{36} \mathrm{H}_{32} \mathrm{IN}_{2} \mathrm{PSe}_{2}$} & $\mathrm{C}_{16} \mathrm{H}_{22} \mathrm{Cl}_{0.50} \mathrm{~N}_{2.50}$ \\
\hline & $\mathrm{PSe}_{2}$ & $\mathrm{PSe}_{2}$ & & $\mathrm{Se}_{2}$ \\
\hline $\mathrm{FW}\left(\mathrm{g} \cdot \mathrm{mol}^{-1}\right)$ & 754.03 & 798.49 & 808.42 & 425 \\
\hline Crystal system & triclinic & triclinic & orthorhombic & monoclinic \\
\hline Space group & $P \overline{1}$ & $P \overline{1}$ & $P 2{ }_{1} 2_{1} 2_{1}$ & $P 2_{1} / c$ \\
\hline$a(\AA)$ & $9.2775(11)$ & $9.3752(5)$ & $9.2747(2)$ & $9.0534(5)$ \\
\hline$b(\AA)$ & $13.5469(16)$ & $13.5967(6)$ & $10.6749(2)$ & $13.1176(6)$ \\
\hline$c(\AA)$ & $14.3091(15)$ & $14.3500(7)$ & $34.3002(6)$ & $16.4261(7)$ \\
\hline$\alpha\left(^{\circ}\right)$ & $82.498(4)$ & $82.051(2)$ & 90.00 & 90.00 \\
\hline$\beta\left(^{\circ}\right)$ & $88.218(4)$ & $87.549(2)$ & 90.00 & $112.672(2)$ \\
\hline$\gamma\left(\left(^{\circ}\right)\right.$ & $83.497(4)$ & $83.173(2)$ & 90.00 & 90.00 \\
\hline$V\left(\AA^{3}\right)$ & $1771.3(4)$ & $1798.15(15)$ & $3395.94(11)$ & $1800.00(15)$ \\
\hline$T(\mathrm{~K})$ & $296(2)$ & $296(2)$ & $296(2)$ & $296(2)$ \\
\hline Cryst. dim. $\left(\AA^{3}\right)$ & $0.23 \times 0.11 \times 0.10$ & $0.28 \times 0.16 \times 0.13$ & $0.22 \times 0.10 \times 0.08$ & $0.25 \times 0.21 \times 0.01$ \\
\hline$Z$ & 2 & 2 & 4 & 4 \\
\hline$D_{\text {calc }}\left(\mathrm{g} \cdot \mathrm{cm}^{-3}\right)$ & 1.414 & 1.475 & 1.581 & 1.568 \\
\hline$\mu\left(\mathrm{mm}^{-1}\right)$ & 2.238 & 3.242 & 3.161 & 4.179 \\
\hline Abs. corr. & multi-scan & multi-scan & multi-scan & multi-scan \\
\hline $\mathrm{T}_{\min }, \mathrm{T}_{\max }$ & $0.744,0.799$ & $0.542,0.656$ & $0.691,0.777$ & $0.366,0.959$ \\
\hline Total refls. & 43521 & 29306 & 24731 & 4122 \\
\hline Uniq. refls. $\left(R_{\text {int }}\right)$ & $8141(0.0375)$ & $8249(0.0298)$ & $7781(0.0247)$ & 4121 \\
\hline $\begin{array}{l}\text { Unique refls. } \\
(\mathrm{I}>2 \mathrm{~s}(\mathrm{I}))\end{array}$ & 5829 & 5578 & 6512 & 2069 \\
\hline$R_{1}$ & 0.0434 & 0.0371 & 0.0327 & 0.0624 \\
\hline$w R_{2}$ (all data) & 0.1222 & 0.091 & 0.070 & 0.1591 \\
\hline GoF & 1.142 & 1.059 & 1.02 & 1.027 \\
\hline Res. dens $\left(\mathrm{e}^{-} \AA^{-3}\right)$ & $0.652,-0.951$ & $0.898,--0.596$ & $0.557,-0.391$ & $0.568,-0.561$ \\
\hline Flack param. & - & - & $0.64(1)$ & - \\
\hline
\end{tabular}




\section{Theoretical calculations}

Theoretical calculations were performed using the Gaussian09 software ${ }^{36}$ at the DFT level employing the B3LYP functional and the 6-311++G(d,p) basis set. Molecular structures of anti-1, syn-1, anti-A, syn-A, fluorine-substituted anti-3 and syn-3 were optimized and frequency calculations were performed in order to check that true energy minima were obtained. Electrostatic potential (ESP) mapped on the $\rho=0.001$ a.u. isodensity surface were then computed with the AIMAll software package; ${ }^{37}$ the maximum of ESP $\mathrm{V}_{\mathrm{S} \text {, max }}$ in the region of the (NC)Se $\sigma$-holes associated with Se atoms were located with MultiWFN software. ${ }^{38}$

Whereas anti-1 optimized under C2 symmetry toward a true energy minimum, syn-1 optimized toward a Cs molecular structure associated with a small imaginary frequency $(-20$ $\mathrm{cm}^{-1}$ ). Further optimization of that structure without symmetry constrain led to a true energy minimum characterized by an intramolecular Se•••Se interaction $[\mathrm{d}(\mathrm{Se} \bullet \bullet \mathrm{Se})=3.958 \AA$, RR = $\left.1.04 ; \alpha(\mathrm{C}-\mathrm{Se} \cdot \bullet \mathrm{Se})=154.6^{\circ}\right)$ ], with the $(\mathrm{NC}) \mathrm{Se} \sigma$-hole of one of the two selenium atoms pointing toward one lone pair of the second chalcogen atom. The Cs constrained syn-1 molecular structure is then reported for comparison purposes, since in that structure the two chalcogen (NC)Se $\sigma$-holes are oriented as in the halide adducts. The same situation occurs for syn-A which was calculated under constrained Cs symmetry (imaginary frequency $=-12 \mathrm{~cm}^{-1}$; the two $\sigma$-holes pointing outward the molecule) and also under C1 [intramolecular Se•••Se interaction $\left.\mathrm{d}(\mathrm{Se} \bullet \bullet \mathrm{Se})=3.692 \AA, \mathrm{RR}=0.97 ; \alpha(\mathrm{C}-\mathrm{Se} \bullet \bullet \mathrm{Se})=169.4^{\circ}\right]$. For fluorine-substituted syn-3 molecule, the Cs symmetry constrained structure is also a saddle point (imaginary frequency $=-9 \mathrm{~cm}^{-1}$; the two $\sigma$-holes pointing outward the molecule) but the unconstrained $\mathrm{C} 1$ symmetry structure does not present the previously observed intramolecular Se•••Se interaction due to an unfavorable relative NCSe orientations $[\mathrm{d}(\mathrm{Se} \bullet \bullet \mathrm{Se})=4.044 \AA, \mathrm{RR}=1.06$; $\left.\alpha(\mathrm{C}-\mathrm{Se} \bullet \bullet \mathrm{Se})=128.4^{\circ}\right]$.

Molecular structures of the (anti-1) $\mathrm{Cl}^{-}$and $\left(\right.$syn-1) $\mathrm{Cl}^{-}$were also optimized using the same calculation conditions and true energy minima were obtained. Basis Set Superposition Error corrected structures and complexation energies were obtained through the counterpoise method of Boys \& Bernard. ${ }^{39}$ More details are given in the Supporting Information file (cartesian coordinates of optimized molecular structures).

\section{Conflicts of interest}

There are no conflicts to declare. 


\section{Acknowledgements}

This work was supported by the French National Agency for Research (ANR 17-CE07-002501 and ANR 17-CE07-0025-02. The EXPLOR mesocentre is thanked for computing facilities (Project 2019CPMXX0984).

\section{References}

${ }^{1}$ (a) J.-M. Lehn, Chem. Soc. Rev., 2007, 36, 151-160. (b) Y. Zhao, Y. Cotelle, N. Sakai and S. Matile, J. Am. Chem. Soc., 2016, 138, 4270-4277.

2 (a) G. Cavallo, P. Metrangolo, R. Milani, T. Pilati, A. Priimagi, G. Resnati and G. Terraneo, Chem. Rev., 2016, 116, 2478-2601. (b) L. C. Gilday, S. W. Robinson, T. A. Barendt, M. J. Langton, B. R. Mullaney and P. D. Beer, Chem. Rev., 2015, 115, 7118-7195.

3 T. Clark, M. Hennemann, J. S. Murray and P. Politzer, J. Mol. Mod., 2007, 13, 291-296.

${ }^{4}$ (a) A. Bauza, T. J. Mooibroek and A. Frontera, Angew chem. Int. Ed., 2013, 52, 12317-12321. (b) A. Bauza, S. K. Seth and A. Frontera, Coord. Chem. Rev., 2019, 384, $107-125$.

5 (a) L. M. Lee, M. Tsemperoli, A. I. Poblador-Bahamonte, S. Benz, N. Sakai, K. Sugihara and S. Matile, J. Am. Chem. Soc., 2019, 141, 810-814. (b) P. Scilabra, G. Terraneo and G. Resnati, J. Fluor. Chem., 2017, 203, 62-74.

${ }^{6}$ (a) P. Scilabra, G. Terraneo and G. Resnati, Acc. Chem. Res., 2019, 52, 1313-1324. (b) K. T. Mahmudov, M. N. Kopylovich, M. F. C. Guedes da Silva and A. J. L. Pombeiro, Dalton Trans., 2017, 46, 10121-10138. (c) L. Vogel, P. Wonner and S. M. Huber, Angew. Chem. Int. Ed., 2019, 58, 1880 -1891. (d) N. Biot and D. Bonifazi, Coord. Chem. Rev., 2020, 413, 213243. (e) C. B. Aakeroy, D. L. Bryce, G. R. Desiraju, A. Frontera, A. C. Legon, F. Nicotra, K. Rissanen, S. Scheiner, G. Terraneo, P. Metrangolo and G. Resnati, Pure Appl. Chem., 2019, 91, 1889-1892.

${ }^{7}$ N. Biot and D. Bonifazi, Chem. Eur. J., 2020, 26, $2904-2913$.

${ }^{8}$ (a) P. Wonner, L. Vogel, M. Düser, L. Gomes, F. Kniep, B. Mallick, D. B. Werz and S. M. Huber, Angew. Chem. Int. Ed., 2017, 56, 12009-12012. (b) P. Wonner, L. Vogel, F. Kniep and S. M. Huber, Chem. Eur. J., 2017, 23,16972-16975. (c) S. Benz, J. Mareda, C. Besnard, N. Sakai and S. Matile, Chem. Sci., 2017, 8, 8164 -8169. (d) S. E. Reisman, A. G. Doyle and E. N. Jacobsen, J. Am. Chem. Soc., 2008, 130, 7198-7199. (e) W. Wang, H. Zhu, S. Liu, Z. Zhao, L. Zhang, J. Hao and Y. Wang, J. Am. Chem. Soc., 2019, 141, 9175-9179. 
${ }^{9}$ (a) M. S. Taylor, Coord. Chem. Rev., 2020, 213, 213270. (b) E. Navarro-Garcia, B. Galmés, M. D. Velasco, A. Frontera and A. Caballero, Chem. Eur. J., 2020, 26, 4706-4713. (c) J. Y. C. Lim, J. Y. Liew and P. D. Beer, Chem. Eur. J., 2018, 24, 14560-14566.

${ }^{10}$ S. Benz, M. Macchione, Q. Verolet, J. Mareda, N. Sakai and S. Matile, J. Am. Chem. Soc., 2016, 138, 9093-9096.

${ }^{11}$ M. Macchione, A. Goujon, K. Strakova, H. V. Humeniuk, G. Licari, E. Tajkhorshid, N. Sakai and S. Matile, Angew. Chem. Int. Ed., 2019, 58, 15752-15756.

${ }^{12}$ (a) M. E. Brezgunova, J. Lieffrig, E. Aubert, S. Dahaoui, P. Fertey, S. Lebègue, J. G. Angyan, M. Fourmigué and E. Espinosa, Cryst. Growth. Des., 2013, 13, 3283-3296. (b) H. Wang, J. Liu and W. Z. Wang, Phys. Chem. Chem. Phys., 2018, 20, 5227-5234.

${ }^{13}$ P. Politzer, J. S. Murray, T. Clark and G. Resnati, Phys. Chem. Chem. Phys., 2017, 19, 32166-32178.

${ }^{14}$ P. C. Ho, P. Szydlowski, J. Sinclair, P. J.W. Elder, J. Kübel, C. Gendy, L. M. Lee, H. Jenkins, J. F. Britten, D. R. Morim and I. Vargas-Baca, Nature Commun., 2016, 7, 11299.

${ }^{15}$ G. E. Garrett, E. I. Carrera, D. S. Seferos and M. S. Taylor, Chem. Commun., 2016, 52, 9881-9884.

${ }^{16}$ M. Macchione, M. Tsemperouli, A. Goujon, A. R. Mallia, N. Sakai, K. Sugihara and S. Matile, Helv. Chim. Acta., 2018, 101, e1800014.

${ }^{17}$ N. Biot and D. Bonifazi, Chem. Eur. J., 2018, 24, 5439-5443.

18 (a) A. F. Cozzolino, I. Vargas-Baca, S. Mansour and A. H. Mahmoudkhani, J. Am. Chem. Soc., 2005, 127, 3184-3190 (b) V. Kumar, Y. Xu and D. L. Bryce, Chem. Eur. J., 2020, 26, 3275-3286. (c) G. E. Garrett, G. L. Gibson, R. N. Straus, D. S. Seferos and M. S. Taylor, J. Am. Chem. Soc., 2015, 137, 4126-4133.

${ }^{19}$ J. Y. C. Lim, I. Marques, A. L. Thompson, K. E. Christensen, V. Felix and P. D. Beer, J. Am. Chem. Soc., 2017, 139, 3122-3133.

${ }^{20}$ A. Dhaka, O. Jeannin, I.-R. Jeon, E. Aubert, E. Espinosa and M. Fourmigué, Angew. Chem. Int. Ed., 2020, in press, DOI 10.1002/anie.202011981

${ }^{21}$ M. Beau, S. Lee, S. Kim, W.-S. Han, O. Jeannin, M. Fourmigué, E. Aubert, E. Espinosa, and I.-R. Jeon, Angew. Chem. Int. Ed., 2020, in press, DOI 10.1002/anie.202010462

22 J. George, V. L. Deringer and R. Dronskowski, J. Phys. Chem. A., 2014, 118, 17, 3193-3200.

${ }^{23}$ O. Jeannin, H.-T. Huynh, A. M. S. Riel and M. Fourmigué, New J. Chem., 2018, 42, 10502-10509. 
${ }^{24}$ (a) H.-T. Huynh, O. Jeannin and M. Fourmigué, Chem. Commun., 2017, 53, 8467-8469.

(b) A. M. S. Riel, O. Jeannin, O. B. Berryman and M. Fourmigué, Acta Cryst. 2019, B75, 34-38.

${ }^{25}$ A. M. S. Riel, H.-T. Huynh, O. Jeannin, O. Berryman and M. Fourmigué, Cryst. Growth Des., 2019, 19, 1418-1425.

${ }^{26}$ V. Kumar, C. Leroy and D. L. Bryce, CrystEngComm, 2018, 20, 6406-6411.

${ }^{27}$ R. Weiss, E. Aubert, P. Peluso, S. Cossu, P. Pale and V. Mamane, Molecules 2019, 24, $4484(1-16)$.

${ }^{28}$ (a) K. Fujita, M. Iwaoka and S. Tomoda, Chem. Lett., 1994, 23, 923-926. (b) T. Wirth, Angew. Chem. Int. Ed., 1995, 34, 1726-1728.

${ }^{29}$ V. Mamane, P. Peluso, E. Aubert, R. Weiss, E. Wenger, S. Cossu and P. Pale, Organometallics, 2020, in press, DOI 10.1021/acs.organomet.0c00633.

${ }^{30}$ S. M. Walter, F. Kniep, E. Herdtweck and S. M Huber, Angew. Chem. Int. Ed., 2011, 50, 7187-7191.

${ }^{31}$ E. Eru, G. E. Hawkes, J. H. P. Utley and P. B. Wyatt, Tetrahedron, 1995, 51, 3033-3044.

${ }^{32}$ D.-R. Hou, M.-S. Wang, M.-W. Chung, Y.-D. Hsieh and H.-H. G. Tsai, J. Org. Chem., 2007, 72, 9231-9239.

${ }^{33}$ G. M. Sheldrick, Acta Cryst., 2015, A71, 3-8.

${ }^{34}$ G. M. Sheldrick, Acta Cryst., 2015, C71, 3-8.

35 J. Farrugia, J. Appl. Crystallogr., 2012, 45, 849-854.

${ }^{36}$ M. J. Frisch, G. W. Trucks, H. B. Schlegel, G. E. Scuseria, M. A. Robb, J. R. Cheeseman, G. Scalmani, V. Barone, B. Mennucci, G. A. Petersson, H. Nakatsuji, M. Caricato, X. Li, H. P. Hratchian, A. F. Izmaylov, J. Bloino, G. Zheng, J. L. Sonnenberg, M. Hada, M. Ehara, K. Toyota, R. Fukuda, J. Hasegawa, M. Ishida, T. Nakajima, Y. Honda, O. Kitao, H. Nakai, T. Vreven, J. A. Montgomery, Jr., J. E. Peralta, F. Ogliaro, M. Bearpark, J. J. Heyd, E. Brothers, K. N. Kudin, V. N. Staroverov, R. Kobayashi, J. Normand, K. Raghavachari, A. Rendell, J. C. Burant, S. S. Iyengar, J. Tomasi, M. Cossi, N. Rega, J. M. Millam, M. Klene, J. E. Knox, J. B. Cross, V. Bakken, C. Adamo, J. Jaramillo, R. Gomperts, R. E. Stratmann, O. Yazyev, A. J. Austin, R. Cammi, C. Pomelli, J. W. Ochterski, R. L. Martin, K. Morokuma, V. G. Zakrzewski, G. A. Voth, P. Salvador, J. J. Dannenberg, S. Dapprich, A. D. Daniels, Ö. Farkas, J. B. Foresman, J. V. Ortiz, J. Cioslowski, and D. J. Fox, Gaussian 09 (Gaussian, Inc., Wallingford CT, 2009).

${ }^{37}$ AIMAll (Version 19.10.12), T. A. Keith, TK Gristmill Software, Overland Park KS, USA, 2019 (aim.tkgristmill.com) 
38 (a) L. Tian and C. Feiwu, J. Comput. Chem., 2012, 33, 580-592. (b) L. Tian Lu and C. Feiwu, J. Mol. Graph. Model., 2012, 38, 314-323.

${ }^{39}$ S. F. Boys and F. Bernardi. Mol. Phys., 1970, 19, 553-566. 
